\title{
Accessing Labour, Resources and Institutions: Women Laborers in Brick Kiln of Jamune Bhanjyang, Tanahun , Nepal
}

\author{
Prakash Upadhyay \\ Associate Professor of Anthropology \\ Tribhuvan university, Prithvi Narayan Campus, Pokhara, Nepal
}

\begin{abstract}
The key argument of this paper is that the changing nature of women's involvement in non-agricultural labor force has added a critical dimension in the development process of Nepal. This relationship between involvement and development has been affected by nature of women's employment, education, family responsibility and state policy. The major objective of this paper is to analyze critical issues, condition, tribulations and options associated with the livelihoods of women labourers working in brick kiln. For meeting the objectives, qualitative and quantitative data from both primary and secondary sources were used. Primary data were collected via self administered questionnaire, interview, observation and case study. The study findings reveal that due to poverty, low education and skills, many rural women are concentrated in low-skilled and low-paid employment in urban brick kilns where they suffer from gender discriminations, exploitations and male chauvinism in salary, working hours, promotion and facilities. Gender relation has been foremost in determining control over and access to labour, resources, institutions and services. Hence, understanding the different role of women and men is critical to understanding how that system affects women labour, reward, punishment, productivity and sustainability in brick kilns. Policies should consider women labourers easy access to education and information on their rights, as well as supportive institutions and legal measures to ensure their safety, gender rights and encourage private sector development in rural areas that can increase job opportunities for rural women hence reducing their brisk migration to urban areas for job. Key words: Bigotry, brick molding, gender equality, kiln, labour laws, patriarchy,
\end{abstract}




\section{Introduction}

Amid the fast population growth and urbanization in Nepal, construction work ranked as the third largest economic sector in the country, persists to grow. The towering demand for building materials has fueled a stipulation for cheap labor and a lack of incentives for clean or socially responsible brick production. According to Good Weave International Report (2015) although work conditions are inhumane, the brick industries in Nepal, provides jobs to thousands of unskilled labourers where over 175,000 women and child workers labor in unhealthy and unsafe conditions. Brick workers are some of the most marginalized of unskilled workers, often bonded by debt to exploitive labor brokers, and working at wages insufficient to pay off recruiter advances. The informal nature of kiln industry that operates on the periphery of communities and with modest government regulation has served to ensconce exploitive labor practices such as bonded, child and women labor. The sector is dominated by migrant and seasonal labourers who live on the kilns during the brick season and have almost no link to local government, community organizations, or representation by workers trade associations. Unrepresented, unfettered, and for the most part superfluous, brick kiln workers have seen little advancement on social, economic, or human rights issues; but with few doable income alternatives they lack the power to perk up their working conditions or pay as fixed by government regulations and International Labour Organization.

Over the past two and half decades Nepalese women's participation in economic activities has moved beyond agriculture into the local market economy. In search for wage employment, women are moving into small business and self employment ventures there by creating many formal and informal opportunities for work. Also, women are ever more migrating to urban or semi-urban areas for employment in industries as brick kilns, cottage and food kilns etc. However, the recognition and accounting of their contribution differs from region to region. Despite the economic necessity impelling many women into the labour force, their work is often considered secondary and frivolous. Women face gender discrimination in pay, fringe benefits, and opportunities for advancement and access to interesting jobs. Additionally, women are still expected to perform the majority of 
household and child securing task, regardless of their work status. The result is that women's work is really never done (Akhter et.al 2014). The recognition and accounting as such also differs in accordance with the nature of work manifested in the modern formal sectors in comparison to traditional informal as well as agricultural sectors. In addition, ruralurban differences of treatment at work place also create differences in the degree of recognition and accounting of the work.

Hunzai (2010) argues that women in Nepal are vital and productive contributors to the national economy but their access to knowledge; skills, resources, opportunities and power still remain rather low. Although women constitute a little over one half of Nepal's population, they rank lower than men in almost every social indicator in the country. Within the tides of poverty, women are the poorest of the poor, a relatively more deprived segment even from among the poor. Gender based discriminations at work place, in addition, is a serious problem. Although legal provisions prohibit discrimination on the ground of gender, institutional exclusion of, discrimination against women is pervasive. Discrimination in employment is one of the most important areas of discrimination. In neoclassical economics theory, labor market discrimination is defined as the different treatment of two equally qualified individuals on account of their gender, race, disability, religion etc. Blau et al (2010) argues that discrimination is harmful since it affects the economic outcomes of equally productive workers directly and indirectly through feedback effects. Darity and Mason (1998) squabble that the standard approach used in identifying employment discrimination is to isolate group productivity differences (education, work experience). Differences in outcomes (such as earnings, job placement) that cannot be attributed to worker qualifications are attributed to discriminatory treatment.

A good place to position the start of theoretical debates about women, class and work is in the intersection with Marxism and feminism. Such debates is shaped not only by academic inquiries but as questions about the relation between women's oppression and liberation and the class politics of the left, trade union and feminist movements. Early development approaches by assuming the wholesale adoption of Western technology, institutions, and beliefs, largely ignored women (Moser, 1993). Boserup's 
(1970) study seriously challenged the argument that benefits from development projects would automatically trickle down to women and other disadvantaged groups in less developed countries. Women working in the different sectors challenged the assumption that modernization would automatically increase gender equality. They began to use the term Women in Development (WID) in their efforts to influence the policies with emphasis on equal opportunity for women, providing basic human needs for all, targeting poor women and their basic human needs, access to development, accurate measurements of women's lived experiences and for improvements in women's access to education, property and better employment. To achieve these goals, they maintained that women must be integrated into development projects and plans and have a say in policy design and implementation (Moser, 1993). However, the WID approach tended to preoccupy itself with women's roles as producers and ignored their domestic labour. It rarely addressed fundamental questions about women's subordination (Overholt et al. 1984).

In the 1970s, radical and orthodox development thinkers and planners agreed on the centrality of poverty alleviation, although they differed on how to bring it about (Jaquette, 1982). At the same time, attempts were made to seek answers for women's development issues in Marxism, which had developed the most thorough critique of modernization theory. However, this approach has little to say about women and fails to question the importance of modernization and economic development. Marxist scholars have generally accepted Friedrich Engels' argument that women's subordination is a consequence of the development of private property and capitalism and that a successful class struggle is necessary (Sargent, 1981).

The radical-feminist critique of Liberal and Marxist feminism, argued that, patriarchy exists in all societies and is the fundamental source of inequality. Anthropologically, this suggests the need to create alternative social institutions, separate from men, within which women can fulfill their needs. Parpart (1989) argues that during the 1970s, this approach has been referred to as Women and Development (WAD) that stresses the distinctiveness of women's knowledge, women's work, and women's goals and responsibilities. It argues for recognition of this distinctiveness and for 
acknowledgment of the special roles that women have always played in the development process (Rathgeber, 1990).

Since the mid-1980s, the emphasis has been on increasing women's economic contribution to increase overall economic efficiency and bring about equity for women (Moser, 1989; Elson, 1992). Some feminists and development theorists dissatisfied with WID and the WAD approaches turned to the Gender and Development (GAD) perspective which emerged in the 1980s as an alternative to WID and WAD. Also called empowerment approach or gender-aware planning (Young et al. 1981; Moser, 1989; Elson, 1992 and Sen and Grown, 1987), it argues that women's status in society is affected by their material conditions of life and by their position in the national, regional, and global economies. It recognizes that women are affected by the nature of patriarchal power in their societies at the national, community, and household levels (Sen and Grown, 1987) and focuses on women's material conditions and class position as well as patriarchal structures and ideas that define and maintain women's subordination. The focus is on relationships between women and men, not on women alone. Gunatilaka (2013) squabble that in South Asia, female participation in labour rates range from around $20 \%$ in Pakistan to almost $80 \%$ in Nepal, which can be explained by differences in social and economic factors. Women in Nepal are less constrained by social norms, though they work mostly in subsistence agriculture, which is driven more by poverty than by choice. In spite of limited education and gender biases, women have been using their skills to create products and to improve economic condition. According to Nepal Labour Force Survey report (2008), there is wide variation between male and female labour force participation as paid employee. It is 26.6 percent for males compared to only 8.3 percent for females, resulting in very low participation rate in paid employment compared to other countries.

Nepalese society is strictly based on patriarchal norms and values. The elemental features of patriarchal culture are the patrilineal inheritance system, controls over women's sexuality and bodies and restraint over women's mobility. On the basis of this cultural practice, women are subordinate in all levels (economic control, body, movement and family lineage). Such practice negatively affects women's esteem, enthusiasm 
and decision making ability in both direct and indirect ways. The gender division of labour has added more work to women with longer working hour for women that might be reflected in health hazards among laboring women.

Though, Nepal's Constitution 2015 has made the provisions for ending the discriminatory legal provisions, ending the gender, cultural and religious discrimination, but in practice, discriminations in different forms persist between men and women in terms of work opportunity and treatment at the organized/unorganized sectors. Acharya (2000) argues that the lack of education, training opportunities, and employer biases and limited mobility due to social responsibilities combine to keep women at lower echelons of the industrial hierarchy. Working women ubiquitously suffer from discrimination typically in pay, promotion and facilities. There are around 700 brick kilns in Nepal and the number is highest in Kathmandu valley (GEFONT/ASI, 2007). Among the kilns workers, majority are women belonging to the socially marginalized castes/ethnicities and economic migrants from different districts. As there is no precise need for skill and education, just a well-built back and the ability to work from morning to evening, the concentration of illiterate/less educated rural poor women is higher in this sector. However, different forces and prohibitions prevent women labour seeking equal opportunities in work with their male counterparts with little recognition and accounting of female labour. Keeping this in view, the prime objective of this study is to study and analyze the critical issues, conditions, tribulations, and options associated with the livelihoods of women labourers in brick kiln.

\section{Data and Methods}

Jamune Bhanjyang, a Village Development Committee (VDC) in Tanahun district, is located in the eastern part of the district. This VDC has a population of 9838 (male population of 4416 and female 5422) living in 2408 individual households. Topographically, this region is having sub tropical climate rich in abundant plain area and the fine clay mud which is quite lush for making bricks. Hence, Jamune Bhanjyang Village Development Committee is known for its brick kilns and production. Bricks produced here are supplied to different parts of Nepal as a vital construction material. 
Among the brick kilns (currently eight brick kilns are functioning in Tanahun district), Machhapuchchhre Brick Kiln located at Jamune Bhanjyang ward no. 8 Kaflethok selected for this study, is the one of the largest and wellestablished brick kiln in terms of productivity and size of employees. As one of the leading and well-established brick kiln of the region, along with male labourers, this kiln represents the women labourers from diverse social-cultural-economic and caste/ethnic backgrounds of the region that has provided an important basis for anthropological studies for generating an important insight in anthropological analysis of women labourers.

The study adopts descriptive research design based on descriptive analytic method of analysis for evaluating the status, conditions and livelihood related tribulations of women labourers in brick kiln. The total number of labourers employed in Machhapuchchhre Brick Kiln is 120; out of these 66 were women labourers working as low-skilled workers. Using the census method, all the 66 women labourers in the kiln at the time of study were selected for the study. Since the entire population is very small, it was reasonable to include the entire population and data has been gathered on every member of the women population. The study has incorporated both primary and secondary data. For validation and comparison of the findings, secondary data were collected from articles, books, published and unpublicized online journals and reports. Primary data were collected from the field via Self Administered Questionnaire, Interview, Observation and Case study. Data was collected using anonymous self-administered questionnaires. Questions were raised to labourers using an unstructured interview schedule. An in-depth observation was made on the labouring pattern of female labourers. The measure of reliability was obtained by administering the same test twice over a period of time to the women labourers. The scores from Time 1 and Time 2 were correlated in order to evaluate the test for stability over time. Validity was ensured that the measure is actually measured what is intended to measure. Few case studies of women labourers were prepared carefully investigating their life histories and experiences. It helped to supplement information on the past and present situation of the women labourers and also to find out their feelings and attitude towards the brick kiln.

\section{Results and Discussion}

The caste and ethnic identities of total 66 women labourers employed 
in Machhapuchchhre brick can be categorized into three broad caste/ ethnic groups; such as Brahmin/Chhetri, Janajati and Dalit. Janajati denotes Gurung, Magar, Tharu and Newar women labourers. The highest proportion of the female labourers i.e. 47 percent is Janajati followed by Dalit whose percentage is around 39. Brahmin/Chhetri women labourers' percent was 14 percent. Most women labourers were middle aged (i.e. 23 to 34) which indicates that middle aged women have soaring burden to earn to support their families. Both married and unmarried women were employed though the percentage of unmarried female was very low. More than 95 percent of women were married whereas only less than 5 percent were unmarried.

The family size of women labourers varies from 2 to 7 with average family size of 4.2. Compared to the national figure of 4.9, the average family size of women labourers in this brick kiln is smaller. Around 74 percent women labourers were living in nuclear family and the rest were from joint family. Around 14 percent of women labourers were illiterate compared to around 86 percent literate. Of the literate labourers, 51 percent of labourers have primary level of education, followed by secondary and informal education: 18.3 percent and 16.7 percent respectively. It reveals that women with low level of education were involved in this kiln as low-skilled labour force.

The work-season of this brick kiln starts by and large from the last week of October and arrangement of seasonal (temporary) labourers in the kiln is done earlier to ensure smooth kiln operation. The temporary labourers of the kiln are mostly from agricultural sector and are contacted before to agriculture season. In other brick kilns located in terai, Kathmandu and other regions, labourers are generally hired through dealers/agents or Naikes (also known as sardar or meth) prior to production season (GEFONT/ASI, 2007). But, self-approached labourers are unbridled in Machhapuchchhre brick kiln. Women labourers have come to this kiln for work without any connection either with owner or any dealer. The involvement of the labourers in this brick kiln is on both temporary (seasonal) and permanent basis.

As brick production engrosses various activities, diverse types of works have to be performed in a single brick kiln. In such condition it is not viable to provide supervision inputs to each and every activity by the owner himself. 
Hence, the overall responsibility of all activities is given to respective Naikes so that owner does not have any burden of monitoring and supervision of labourers. Four types of works are important in brick kiln hence there are four types of Naikes as well. Technician head (b) Brick Moulding Naike (c) Unbaked Brick Carrying Naike, and (d) Baked Brick Carrying Naike. In Machhapuchchhre brick kiln, all the Naikes are males who control their respective sectors including women labourers from respective sectors who have different reasons to work.

\section{Reasons for Working as Labourers in Brick Kiln, Income and Facilities}

Various reasons were spelled out by women labourers for working in brick kiln. Of all reasons, the highest response is poor economic condition (78.7\%). It was for those who have larger families, who do not have any other income sources or if having not sufficient other income sources to support their families. The other main two reasons were: to increase earning capacities (15.2\%) and to be self dependent (6.1\%).

The monthly salary of the permanent women labourers in Machhapuchchhre brick kiln, without overtime, ranges from Rs. 10,000 to Rs. 12,000 depending on the type of work. Compared to seasonal (temporary) workers, salary of permanent workers is high. Temporary workers were usually paid daily wages ranging between Rs. 300 to 400 depending on types and hours of work. Depending on the types of work Rs. 40 to 70 was paid to both permanent and seasonal labourers for each hour of overtime.

Without overtime, majority female (80.3\%) workers had monthly income ranging between Rs. $10,000-12,000$ which was followed by less than 10,000 (13.6\%) and more than $12,000(6.1 \%)$ respectively. Including the overtime income, around 68 percent had monthly income between Rs. 10000-12000. Around 31 percent of the female workers had monthly income more than Rs. 12,000 . However, still just about 2 percent had monthly income less than Rs. 10,000 after including the overtime income. Around 83 percent were the beneficiaries of overtime facilities occasionally, whereas around 18 percent have not found any overtime facilities. Those who have overtime facilities have earned from extra hours work.

Similarly, the kiln has provided facilities such as snack, tea, Dashain 
allowance and the residence facilities to the permanent workers. However, all women labourers are not the beneficiaries of such facilities. Of the 66 women labourers, around 39 percent has got tea and snack facilities during the working period. Likewise, 40.9 percent have not got any such facilities. Around 3 percent got Dashain allowance ( 1 month salary) and 22.7 percent have residence facilities. These facilities were provided to permanent staffs working continuously for the last five years. However, the residence facility has been provided to limited permanent staffs. Likewise, the kiln has provided other facilities to permanent workers such as; yearly grade to all the workers (one day salary), yearly leaves ( 11 days casual leave and 15 days sick leaves), 35 days maternity leave. In case of any kind of accidents and hazards inside the kiln, medical treatment was rendered by the kiln and in emergency conditions loans were provided by the kiln to the worker, which was deducted regularly from their monthly salary.

\section{Work Types and Working Conditions}

The daily normal working hour was 8 hours per day. However, including overtime work, most of the workers worked more than 8 hours per day. Most of the women labourers (56.1\%) were involved with medium types of works, whereas 39.4 percent are involved with easy types of work and the only 4.5 percent have hard works. The medium and easy type of work was filling and packing of the materials, brick molding which also include mud digging, mud preparation, sand carrying, brick carrying and piling of bricks etc. Hard types of works were baking clay and bricks, carrying heavy loads, loading and unloading weighty materials, wood/coal breaking, wood stacking, wood/coal carrying etc. Hard types of works were mainly done by male workers. Male labourers were involved in vital skilful works as naikes, mistri, sub-technician, supervisor, firemen, and water management.

\section{The Quality of Job Matters: Job Satisfaction, Tribulations and Exploitations} Labourers could not quit the job during the operation period of the kiln. Labourers once entered in the kiln work for a fix period of time with verbal or written bond, could not quit until the seasonal kiln work is accomplished. It is the case of seasonal (temporary) labourers. For the permanent labourers, it was virtually impossible to quit the job because 
of their provision of provident fund and other legal obligations. It was construed that preponderance of women labourers (59.1) were contented with their job. However, around 41 percent of the labourers informed that they were not satisfied with their job.

Table 1

Women Labourers' Job Satisfaction

\begin{tabular}{lrr}
\hline \multirow{2}{*}{ Job Satisfaction } & \multicolumn{3}{c}{ Female Labourers } \\
\cline { 2 - 4 } & Frequency & \multicolumn{2}{c}{ Percent } \\
\hline Satisfaction & 39 & 59.1 \\
Not satisfied & 27 & 40.9 \\
Total & 66 & $\mathbf{1 0 0 . 0}$ \\
Reasons for Dissatisfaction & 12 & 44.4 \\
Low salary & 8 & 29.6 \\
No job security & 7 & 25.9 \\
Low wages for low quality hard work & $\mathbf{2 7}$ & 100 \\
Total & &
\end{tabular}

Source: Field Survey, 2015

Of the labourers dissatisfied with their job, 44 percent reported that their salary was low. Likewise, 29.6 percent of the labourers were discounted due to job insecurity. Around 25.9 percent were disgruntled due to low salaries for difficult and tiresome less quality works. The job satisfaction status of women labourers has been elaborated in these cases.

\section{Case I: Mero Bhagya Jageko Cha: A Story of Brick Molding Labourer Sonu Magar}

My name is Sonu Magar (name changed). I am 29 years old born in poor family in a remote village of Lamjung district. I approached to this kiln myself and have been working here as brick molding labourer since the last 6 years. I am married, and my husband has been working as a labourer in India. . But he has not sent any amount of money. Me and my family lives in rented house with two rooms. I must say that I have been discriminated in getting official residence. My family is nuclear family. My family size is only 4 which include two sons. I am the head of the households due to the absence of my 
husband. I had attained secondary education and my husband has also secondary level of education. I know the importance of education in human life and hence providing a good education to my son in a boarding school. I am turned as permanent worker, last year. My monthly salary is Rs. 12,000 per month. However, I earn Rs. 14,000 per months including overtime works. The monthly expenditure of my family is around Rs. 14,000. I also get Dashain allowance and other facilities as snacks and tea. So, I am satisfied with this job and salary. I am happy to earn and contribute to my family. But there is no labour union in this brick kiln to raise labourers' legitimate rights, which I think is necessary. The behaviour of the management and administration is good towards all the workers and there is good recognition and accounting of our labour in this kiln. So, I take the kiln as my own home and all the staff as my own family members. After employing here, mero bhagya Jageko cha (My fortune has risen). The socio- economic status of my household has improved over the years.

\section{Case II: An Anecdote of Heavy Load Carrying Labourer: Rita Nepali} I am Rita Nepali (name changed) 39 years old married women. I have been working in this kiln since the last 7 years. Few years back my husband died in public vehicle accident. I am living with my two children in rented rooms. The official residence has been provided more to the male workers than female workers. I am the head of the household and responsible to manage all the households' cost including children's education. My children are in public school in grade 8 and 5. I am thinking to send younger son to boarding school but will not be able to manage the expenses. I am a permanent worker. My monthly salary is Rs. 16,000 per month with overtime. I am involved with hard and complicated types of works such as carrying heavy loads, loading and unloading the materials hence my salary is comparatively high. The monthly expenditure of my family is around Rs. 14,000. I also get Dashain allowance and other facilities. So, I am satisfied with this job and salary. Because of this Job I am immune to poverty and can hold household expenses. If I do not have this employment, it would have been impossible 
for me to manage expenses. I have not faced any problems from co-workers as well as management and administration.

Owing to stiff labour depending on types of work, the brick kiln has provided economic opportunities to less educated, poverty-stricken women of remote rural areas. But the quality of employment and the facilities provided matters in which socially constructed gender roles and prejudice play a vital role. Heyzer and Hashim (1991) argue that gender is the socially constructed roles ascribed to men and women. These social constructed roles often take the form of sexual division of labour that allocates to women the most tedious and labour intensive work and limits women's access to and control over resources. Another construction is the social structures and attitudes of patriarchy and culture that ascribe subordinate position to women with regard to economic and social rewards and involvement. Practical gender needs relate to women's daily needs in caring for themselves and their children, whereas strategic gender interests relate to the task of changing gender relations and challenging women's subordinate position (Molyneux 1985; Moser, 1989). Gender based discrimination and exploitative activities either by management and other co-workers determine the level of involvement of women in the economic activities in kiln. As most of the women involved in kiln are less educated they suffer from problems entrenched to gender bias such as; wage discrimination and working environment. Of the total women labourers, 71 percent reported that they have not suffered from any kinds of discrimination. However, 29 percent labourers testified that they suffered from discriminations and are facing different tribulations. The major types of discrimination against women were gender based discrimination on work and in getting official residence (68\%), long working hours (15.78\%) and different salary for the same work (15.78\%). The cases of exploitations were also reported.

Of the total 66 labourers, around 49 percent reported that they were exploited on one or other occasions. The major types of exploitation were labour exploitation (82.4\%) and wage exploitation (17.6\%). Occasionally they were exploited by male workers (44.1\%), kiln owner/manager (38.2\%) and kiln administrators (17.6\%). But, no any cases of sexual harassment 
were reported by women labourers. Because of exploitations and heavy work burden, most of these women labourers are having health hazards such as backache, hand/leg related pain, headache, ear pain, eye pain and fever. The under mentioned case elaborates the stipulation.

\section{Table 2}

Cases of Exploitations Once or Occasionally

\begin{tabular}{|c|c|c|}
\hline Exploitation & Frequency & Percent \\
\hline Yes & 34 & 49.3 \\
\hline No & 32 & 50.7 \\
\hline Total & 66 & 100.0 \\
\hline \multicolumn{3}{|l|}{ Types of Exploitation } \\
\hline Labor exploitation & 28 & 82.4 \\
\hline Wages exploitation & 6 & 17.6 \\
\hline Total & 34 & 100.0 \\
\hline \multicolumn{3}{|l|}{ Exploiting Agency } \\
\hline Male workers & 15 & 44.1 \\
\hline Owner/manager & 13 & 38.2 \\
\hline Kiln administrators & 6 & 17.6 \\
\hline Total & 34 & 100.0 \\
\hline
\end{tabular}

Source: Field Survey, 2015

Case III: Ke Garne, Aimai Ko Janma Hareko Ko Karma: Tale of Gender Discrimination and Exploitation on Brick Carrying Labourer: Rama G.C.

I am Rama G.C.(name changed) 38-year-old married woman born in remote village of Tanahun district. I have been working in this kiln for about 12 years. I am a permanent worker. I live with my family in a rented house nearby kiln. I have been discriminated in getting official residence. My family includes husband, three children: two sons and one daughter. I have primary level of education. I have positive attitudes towards the importance of education. I am providing education to my children possible only through my hard labour in brick kiln. My husband is a labourer in a construction company and his income is not enough to accomplish my goal to provide education to my children in private boarding school. Hence, I am compelled to work in brick kiln. The monthly expenditure of my family is around Rs. 18,000 . 
My salary is Rs. 11,000 per month and I manage my household expenses with my husbands' income which is 8,000. I am involved with the work of brick carrying. I am deprived of overtime facility. Actually, I am not satisfied with my salary.. Male workers are getting more salary compared to women labourers. Sometimes, I have faced problems from co-workers as well as management and administration. There are gender based discriminations in types of work, salary, working hours and other facilities. Different salaries are provided to male and women labourers for the same work. As most of the women are less educated but straight away need money to survive, they suffer from different kinds of gender bias such as; humiliation from senior employee and male administrators, wage discrimination. I and most women labourers do low quality hard works, face major health hazards as hand and leg related pain, backache, headache, ear pain, eye pain and fever. I and my family need job for survival. Also, I am a permanent worker with the provision of provident fund and other facilities, hence, cannot quit the job without any alternative job. I need to think about my family and struggle for them 'Ke Garne, aimai ko janma hareko ko karma' (To be born as a woman is a doomed fate).

The cases of exploitations are invasive where there is a presence of labourers. In Machhapuchchhre brick kiln, there is large involvement of labourers both women and man, but there is no labour union in this brick kiln to raise the issue of labourers legitimate rights. As brick kiln is a labour intensive industry, arrangements of labourers in brick kiln is one of the crucial factors and is a challenging job. The women labourers of the kiln are mostly from agricultural sector, less educated, involved with difficult low quality works and in the case of temporary workers who are contacted prior to agriculture season; there are high chances of gender bigotry, mistreatment and less recognition and accounting of their labour. The radical-feminist and Marxist feminism argument that patriarchy exists in all societies and is the fundamental source of inequality is intricately linked with the cases of brick kiln women labourers involved with low quality hard works which demands for to create alternative social institutions, separate from men, within which women can accomplish their needs that hassle 
the exclusivity of women's knowledge, women's work, and women's goals and responsibilities. This also calls for acknowledgment and recognition of the distinctiveness and the special roles that women have played in the economic development of kiln and upliftment of their family through their labour. Brick kilns are registered with the government, and thus are obliged to abide by the regulations especially labour laws and regulations, but in reality, they are outside the government regulations especially on laborer's fundamental rights, health, sanitation and safety that are vital for kiln workers physical and mental fitness.

\section{Conclusion and Policy Recommendations}

The trends of gender development in Nepal suggest that the situation is improving over the years since the political change of 1990 with the changing nature of women's involvement in non-agricultural labor force that has been a critical dimension of the development process. However, this relationship between involvement and economic development is far from straightforward because women's employment is determined by a range of multifaceted factors, including education, family size and responsibility, type of job and state policy. Due to poverty, low level of education and skills, poverty-stricken rural women are concentrated in low-skilled, low quality and low-paid jobs in kiln where they are tormented by gender based discriminations and exploitations in salary, promotion and other facilities.

Gender equality and economic development go together. Gender is the socially assembled roles ascribed to men and women that often take the form of sexual division of labor that allocates to women the most tedious and labour intensive work and limits women's access to and control over development resources. It is the key dimension of social difference that affects people's experiences, concerns and capabilities in managing the available resources. As seen from this study, gender is an important factor determining control over and access to labour, resources, institutions and services. Despite reporting of bigotry, the attitude of the kiln owner was satisfactory but there were instances of male chauvinism and gender based discriminations by male co-workers. The facilities provided to them were reasonable, but many women were discontented with their jobs 
and salary. Lack of skill and low level of education was the main reason behind the lower status of women causing their involvement in low-paid and low-skilled works in brick kiln. Higher and vocational education can increase women's participation and empowerment in managerial and administrative works of kiln.

Comprehending different roles and responsibilities of women and men is critical to understanding how changes to that system will affect women labour, reward and punishment and, hence, productivity and sustainability. At the policy level, government need to be strict on enforcement of legal arrangements to ensure rights of workers at recruitment, salary, facilities, safety, and health/sanitation and should actively support formation of kiln laborer's trade unions so that workers in the kilns gather under the union umbrella for collective bargaining and protection of their rights. Policies can be made on exploitation free gender labeling to the brick kilns and the brick buyers can be made aware leading to social pressure among brick kilns for decent gender based labour practices.

Policymakers should be demure with whether women can have entrance to better jobs and take advantage of new labor market opportunities that arise as new economic opportunities are created, in so doing, can contribute to the family and the development process itself. Hence, policies should mull over both supply- and demand-side dimensions, including access to better education and training programs and access to informative materials on women labourers rights, as well as other supportive institutions and legal measures to alleviate the burden of domestic responsibilities, enhance workplace safety conditions, discourage workplace gender discrimination and encourage private sector development in industries in rural areas that can increase job opportunities for women in their own region. This will disrupt the fast migration of poverty-stricken rural women to urban areas for employment in brick kilns.

ACKNOWLEGEMENT: I am extremely indebted to Prof. Dr. Vikash K.C. for his all-time untiring, prolific and pragmatic support and constructive academic suggestions on my research works. I am grateful to him for his productive encouragement and relentless support to enhance my occupational and academic career. This research work is a venture of the researcher under 
the aegis of M.A. anthropology thesis writing students' research and fieldwork program, Prithvi Narayan Campus, Tribhuvan University, Nepal.

\section{References}

Acharya, M. (2000). The Statistical Profile on Nepalese Women. Kirtipur, CEDA; 6-19.

Akhter, Sayeed Mohammed et al. (2014). Reasons for Doing Job outside Household and Difficulties Faced by the Working Women of Bangladesh. International Journal of Social, Behavioral, Educational, Economic, Business and Industrial Engineering 8 (1): 7-13.

Blau, Francine et al. (Eds.) (2010). Differences in Occupations and Earnings: The Role of Labor Market Discrimination. In 6th international Eds. The Economics of Women, Men, and Work. Harlow: Pearson Education Journal; 14-19.

Boserup, E. (1970). Women's Role in Economic Development. London, Allen \& Unwin; 67-74.

Central Bureau of Statistics (CBS) (2011). National Population and Housing Census (NPHC). Kathmandu: National Planning Commission Secretariat; 02.

Darity, William, Mason, Patrick (1998). Evidence on Discrimination in Employment: Codes of Color, Codes of Gender. Journal of Economic Perspectives 12 (2): 63-90. Doi:10.1257/jep.12.2.63. JSTOR 2646962.

Elson, D. (1992). (Eds.) From Survival Strategies to Transformation Strategies: Women's Needs and Structural Adjustment. In Beneria, L.; Feldman, S. Eds. Unequal Burden: Economic Crises, Persistent Poverty, and Women's Work. Boulder: West View Press; 26-48.

GEFONT/ASI (2007). Nepal: Labour under the Chimney, A Study on the Brick Kilns of Nepal. GEFONT Publication, 104: 7-17.

GoodWeave International Report (2015). Better Brick Nepal Program Information. Kathmandu, Global Fairness Initiatives, Humanity United; 2-11.

Gunatilaka, R. (2013). Women's Participation in Sri Lanka's Labour Force:

Trends, Drivers and Constraints. Colombo, Sri Lanka: ILO; 5-17.

Heyzer, N., Hashim \& Rita-Raj (1991). Gender Sensitivity in Development 
Planning: Implementation and Evaluation: Report of APDC subregional workshops. Asian and Pacific Development Centre, Social Science; 69-78.

Hunzai, K. (2010). The Poverty Status of Female headed Households in Nepal. Sustainable Mountain Development ICIMOD, 57: 14-17. Jaquette, J. (1982). Women and Modernization Theory: A Decade of Feminist Criticism. World Politics, 34(2): 267-284.

Molyneux, M. (1985). Mobilization Without Emancipation: Women's Interests, State and Revolution in Nicaragua. Feminist Studies, 11(2): 227-254.

Moser, C. (1989). Gender Planning in the Third World: Meeting Practical and Strategic Needs. World Development, 17(11):1799-1825.

Moser, C. (1993). Gender Planning and Development: Theory, Practice and Training. London: Routledge; 41-57.

CBS (2008). Nepal Labor force sumer. (2008). Central Bureau of Statistics, National Planning Commission (NPC), Kathmandu.

Parpart, J. (1989). Women and Development in Africa: Comparative Perspectives. University Press of America, Lanham, MD; 34-56.

Rathgeber, E. (1990). WID, WAD, GAD: Trends in Research and Practice. Journal of Developing Areas, 24(4):489-502.

Sargent, L. (1981). Women and Revolution. Boston: South End Press; 13-21. Sen, G.; \& Grown, C. (1987). Development, Crisis and Alternative Visions. New York: Monthly Review Press, 36-41.

Young, K.; Walkowitz, C.; \& McCullagh, R. (1981). Of Marriage and the Market. Berkeley: University of California Press; 61-77. 